\title{
TRANSFORMACÕES METROPOLITANAS: São Paulo e Salvador
}

\author{
Inaiá Maria Moreira de Carvalho" \\ Suzana Pasternak \\ Lúcia Machado Bógus:
}

\begin{abstract}
Este artigo se propõe a discutir os impactos do processo de globalização sobre as grandes metrópoles brasileiras com base em uma análise comparativa da trajetória recente de São Paulo e Salvador, que oferece ricos elementos para essa discussão. Partindo da literatura atual sobre esse tema, ele analisa até que ponto os fenômenos associados ao referido processo estariam levando a maiores transformações na estrutura social e urbana dessas aglomerações. Constata, com esta análise, que elas apresentam certa estabilidade ao lado de algumas mudanças, cuja diversidade e complexidade não vêm sendo contempladas pelas formulações teóricas mais correntes.
\end{abstract}

PALAVRAS-CHAVE: metrópoles, globalização, transformações metropolitanas, São Paulo, Salvador.

\section{INTRODUÇÃO}

Os impactos do processo de globalização sobre as grandes metrópoles têm despertado um significativo interesse e provocado discussões entre os estudiosos da questão urbana. O presente trabalho apresenta algumas reflexões sobre essa questão, com base em uma análise comparativa da trajetória recente de duas cidades que oferecem ricos elementos para a referida discussão: São Paulo, a mais populosa e importante metrópole brasileira, considerada por alguns como a "cidade global" do

* Doutora em Sociologia. Professora do Mestrado em Políticas Sociais e Cidadania da Universidade Católica do Salvador e do Programa de Pós-Graduação em Ciências Sociais da Universidade Federal da Bahia-UFBA. Pesquisadora do Centro de Recursos Humanos CRH/UFBA dessa Universidade. Bolsista de produtividade em pesquisa do CNPq e coordenadora do núcleo do INCT/Observatório das Metrópoles de Salvador.

Estrada de São Lázaro, 197. Cep: 40.210-730. Federação. - Salvador - Bahia - Brasil. inaiammc@ufba.br

* * Doutora em Saúde Pública. Professora titular da Faculdade de Arquitetura e Urbanismo. Coordenadora do núcleo do INCT/Observatório das Metrópoles de São Paulo e bolsista de produtividade de pesquisa do CNPq. ahu@edu.usp.br

*** Doutora em Arquitetura e Urbanismo. Professora titular da Pontifícia Universidade Católica de São Paulo, Editora da revista Cadernos Metrópoles e bolsista de produtividade em pesquisa do CNPq. lbogus@pucsp.br. país, e Salvador, a terceira maior capital, que se destaca pela sua história e sua cultura e apresenta características típicas do Brasil menos desenvolvido.

Como se sabe, das últimas décadas do século $\mathrm{XX}$ aos primeiros anos deste novo milênio, o avanço tecnológico, a transnacionalização cada vez maior das atividades econômicas e a emergência de novos padrões de organização da produção e de um espaço global de acumulação tiveram amplas consequências sobre os vários territórios. Conformou-se uma nova geografia que qualifica e desqualifica os diversos espaços em função de fluxos mundializados, nos quais cidades, polos e regiões tendem a integrar uma imensa rede, onde grandes empresas aproveitam vantagens locacionais e valorizam seus capitais em um número crescente de áreas e atividades, produzindo profundas mudanças na divisão territorial do trabalho. Esses fenômenos estariam interferindo direta e decisivamente no desenvolvimento das grandes cidades, transformando algumas delas em locais estratégicos para a gestão global da economia, concentrando o poder econômico, a sede das grandes corporações, o controle dos meios de comunicação e os serviços de 
ponta (Sassen, 1991; Veltz, 1996; Borja; Castel, UM POUCO DE HISTÓRIA

1996; Marcusen; Kenpen, 2000).

Analisando as transformações em curso, da perspectiva de uma sociedade "pós-industrial”, a partir das considerações teóricas de Sassen, alguns autores têm considerado que a globalização estaria produzindo profundas mudanças na estrutura produtiva, social e urbana dessas metrópoles. Ressaltam, entre elas, a perda da relevância das atividades industriais e do proletariado industrial, o crescimento do terciário e do emprego em serviços e a substituição da estrutura de classes sociais no espaço urbano, ampliando as desigualdades, as distâncias e a segregação, com tendência a uma polarização social e urbana.

Embora essas considerações se reportem à experiência de países desenvolvidos, ou, mais precisamente, a algumas das suas "cidades globais", elas têm pautado o debate sobre o desenvolvimento e as transformações das últimas décadas nas metrópoles da América Latina e do Brasil onde, até o presente, ainda influenciam estudiosos e planejadores. Contudo, investigações efetuadas em cidades da Europa, do Brasil e de outros países da America Latina não têm confirmado a existência de tendências universais no que tange ao seu desenvolvimento, nem às teses de polarização entre os mais ricos e mais pobres ou a uma tendência à dualização do espaço urbano. É verdade que as grandes cidades tendem a ser tocadas pelo processo de mundialização da economia e pelos impactos dele decorrentes. Todavia esse envolvimento depende da natureza e do alcance desse processo (que não é único nem converge para um só modelo de cidade), que é mediado por um conjunto de determinantes nacionais ou locais e tem sua dinâmica definida pela continuidade e pela transformação. Aí o pré-existente condiciona a existência do novo, que, em muitos casos, já começara a se esboçar no passado. As trajetórias recentes de São Paulo e de Salvador são bem ilustrativas a esse respeito, como será visto nas análises que se seguem.
Com cerca de 10.970.942 habitantes, segundo a projeção de população para 2010, São Paulo é o núcleo de maior região metropolitana do país, com 39 municípios e quase 20 milhões de moradores. Na metrópole paulista concentra-se quase a metade dos residentes no Estado. A Grande São Paulo integra com Tóquio, Seul, Cidade do México, New York e Mumbai o rol das 6 maiores aglomerações humanas do planeta.

A Vila de São Paulo foi fundada em 1554 por padres jesuítas, que aí estabeleceram um colégio, no âmbito de uma política catequizadora em relação aos índios. Alocaram o colégio numa colina, entre os rios Tamanduateí e Anhangabaú. Até meados do século XIX, a cidade tinha pouca importância para a economia brasileira, centrada no cultivo da cana de açúcar no Nordeste e na exploração do ouro no eixo Minas Gerais - Rio de Janeiro. Mas, já no século XVII, a vila despontava como local de partida das entradas e bandeiras, expedições que desbravaram territórios para escravizar indígenas, garantir posse de terras e procurar minérios preciosos.

"No fim do século XVI, a cidade de São Paulo continha mais ou menos 120 casas, amontoadas no alto do morro" (Morse, 1970, p. 32). A vida rural era mais importante: o local preferencial de moradia era a fazenda; a casa da cidade era mero alojamento para visitas temporárias. O planalto paulista tinha sua base econômica na agricultura de subsistência. O descobrimento do ouro, nos fins do século XVII, em nada auxiliou o desenvolvimento da vila. Pelo contrário, muitos paulistas migraram para as zonas de mineração. De outro lado, rotas fluviais e terrestres foram se desenvolvendo entre São Paulo, Minas Gerais e Mato Grosso, fazendo de São Paulo um entreposto comercial. Em 1765, a população foi estimada em 6 a 7 mil habitantes, incluindo aí os escravos (1970). Em 1836, a população da cidade alcançava cerca de 22 mil habitantes.

A posição econômica da cidade mudou com a expansão da cultura do café na província de São 
Paulo. A primeira zona a ser favorecida pela produção intensiva do café foi o vale do Paraíba, tributária do Rio de Janeiro. Dado o rápido e constante aumento das plantações de café após a Independência, a lavoura cafeeira expandiu-se para o noroeste da capital. Essa nova região apresentava certas vantagens em relação ao vale do Paraíba: não era montanhosa, possuía grandes faixas de terras roxas, extremamente favoráveis à plantação do café. Para a cidade de São Paulo, a importância desse deslocamento territorial da cafeicultura foi crucial: um vasto e rico interior agrícola tornava-se tributário da capital e de seu porto, Santos. A partir de 1867, ano em que foi implantada a primeira ferrovia na cidade, interligando Santos e Jundiaí, seus vales foram sendo atravessados por ferrovias. A capital aumentou sua população para cerca de 32 mil moradores em 1870, dos quais um terço era escravo. Entroncamento ferroviário, sede de uma província em plena expansão, a cidade passava por uma importante transformação urbanística, social e econômica.

São Paulo, na virada do século, propiciou a acumulação de capitais e atraiu um intenso fluxo de migrantes europeus. "Os novos barões do café não se orientavam pela visão de uma escravocracia agrária, por si suficiente, de tipo colonial" (Morse, 1970, p.161). Para suas necessidades de mão de obra, incentivaram um sistema de parcerias com imigrantes europeus para o trabalho nas fazendas de café. Estima-se que, entre 1888 e 1900, passaram por São Paulo quase 900 mil imigrantes, dos quais $70 \%$ eram provenientes da Itália. Os dados populacionais da cidade mostram um forte crescimento populacional; em 1872, a população da cidade era de 23.243 pessoas; já em 1886, esse número dobrava para 44.030 moradores; em 1890, a cifra crescia para 64.934 habitantes, que chegaram a 192.409 em 1893, numa taxa total de crescimento de $10,6 \%$ anuais no período. Segundo Morse (1970, p.2239), um grande percentual dessa população era constituído de estrangeiros: entre 1872 e 1886, a proporção de estrangeiros passou de $8 \%$ para $25 \%$ do total. Como explicar que os migrantes rurais tenham se mudado para a cidade? De um lado, o colono era livre e assalariado. Depois de cumprida sua obrigação para com o proprietário de terras que tinha subvencionado sua vinda, estava livre para se mudar, já que não possuía terras. De outro, muitos desses imigrantes, mesmo subvencionados, acabaram por permanecer na capital. Estima-se que apenas dois quintos acabaram por ir para a agricultura na década de 1890. Em 1890, São Paulo chegou a 239.820 residentes.

Nesse momento de intensos fluxos migratórios, a cidade viveu seu primeiro surto industrial, baseado principalmente nas indústrias têxteis e alimentícias. Nos anos 1920, a indústria paulista passou por um grande processo de expansão, já iniciado por ocasião da Primeira Guerra. O colapso das linhas de comércio internacional propiciou o início do processo de substituição de importações, voltado para a produção nacional de bens de capital e de consumo para o mercado interno. A consequência dessa industrialização em larga escala foi um intenso crescimento demográfico, que aumentou a demanda por moradia e terra, provocando uma carestia geral com inflação, além do aparecimento de um proletariado urbano e de uma nova elite, já não mais ligada ao café, ao comércio ou finanças.

A expansão da rede de transportes coletivos e o surgimento do ônibus por, volta de 1924, permitiu que novas áreas fossem loteadas, expandindo-se o perímetro urbano. Assim, se, num primeiro momento, a expansão da cidade para áreas mais distantes do centro se deu a partir de subúrbios ferroviários, na década de 30, ampliaram-se os caminhos servidos por ônibus. A ocupação do solo ligou-se ao famoso tripé casa própria autoconstrução-loteamento de periferia, criando um tecido urbano rarefeito e pouco denso: em 1960, a densidade demográfica bruta registrava apenas 24,6 hab./ha, índice que atingiu 70,8 hab./ha em 2004. A cidade já apresentava zonas bem definidas: zonas de moradia burguesa nos maciços, e bairros populares nas baixadas dos rios e ao longo das ferrovias. A expansão da periferia pela metrópole ocorreu principalmente a partir da década de 70, quando inúmeros loteamentos foram abertos 
nas periferias dos municípios limítrofes, ampliando a própria periferia da cidade. A política habitacional praticada pela COHAB nos anos $70 \mathrm{e}$ início de 80 reiterou a periferização dos moradores de baixa renda, com a construção de grandes conjuntos habitacionais em áreas limítrofes da capital, que serviram de ponta de lança para favelas e loteamentos, regulares e irregulares. O território metropolitano, cada vez mais, estruturou-se por um sistema rodoviário. Esse último, que possibilitou a ocupação de áreas cada vez mais distantes dos centros urbanizados em locais desprovidos dos mais básicos equipamentos urbanos, foi um dos responsáveis pelo chamado padrão periférico que ainda domina a organização física da metrópole. De outro lado, nota-se a verticalização das zonas centrais e a consolidação do centro-sudoeste da cidade como polo privilegiado, onde se concentram comércio, serviços e bairros residenciais de alta renda. Além disso, a descentralização das atividades industriais e o espraiamento da moradia popular de baixa renda expandiram a área urbanizada da metrópole (a área urbanizada ocupava $874 \mathrm{~km} 2 \mathrm{em} 1962$ e sobe para $2.139 \mathrm{~km} 2 \mathrm{em}$ 2002). Em 1950, a cidade de São Paulo tinha mais de 2 milhões de habitantes e cresceu mais de 5\% nas décadas de 50 e 60, atingindo quase $6 \mathrm{mi}$ lhões de moradores em 1970. sos municípios; pela escala de vários milhões de população residente e (ou) exercendo atividades nessa área; e pelo desenvolvimento de um sistema complexo de polos de concentração de atividades secundárias e terciárias vinculadas a distintos ramos de atividade econômica (Bógus; Pasternak, 2009, p.8). Além do município de São Paulo, onde se concentram sedes de bancos, grandes empresas nacionais e internacionais, serviços especializados e a residência de possuidores de grandes fortunas (estima-se que $60 \%$ dos milionários brasileiros residam nesse município) e de categorias médias, a metrópole passa a agregar um amplo conjunto de municípios. Como assinalam Bógus e Pasternak (2009), alguns são de tipo popular, servindo de residência principalmente para trabalhadores do terciário não especializado, trabalhadores agrícolas e operários da construção civil; outros do tipo operário industrial, com diversidade elevada de operários da indústria moderna, ou operários tradicionais, onde se concentram operários da indústria tradicional; alguns são municípios da elite industrial, redutos tradicionais das indústrias metalúrgica e automobilística, área importante de serviços ligados à indústria e eixo de expansão de moradias da elite; e, finalmente, alguns municípios têm ainda uma base agrícola, sediando importantes reservas ecológicas e florestas da região metropolitana.

Já Salvador, com cerca de 2.948.733 de habitantes, segundo a projeção de população para 2010, constitui a terceira maior cidade brasileira e concentra quase $80 \%$ da população de uma Região Metropolitana com 3.799.588 moradores. Fundada pelos colonizadores portugueses em 1549, Salvador sediou o governo geral do Brasil até 1763 como a mais importante cidade do país. Mas, com a transferência da capital do país para o Rio de Janeiro, o declínio da base exportadora local, a concentração industrial no centro-sul e o predomínio econômico dessa região no processo de desenvolvimento brasileiro, Salvador foi afetada negativamente e experimentou um longo período de estagnação econômica e populacional. Esse período se estendeu quase até a metade do século XX, quando a cidade passou a ser atingida por intensas transformações. 
Na década de 1950, a descoberta e a exploração de petróleo em municípios de sua área de influência (por algumas décadas a principal responsável pela produção nacional) estimulou o crescimento populacional e urbano da cidade e de alguns municípios que hoje compõem a sua região metropolitana. Na década de 1960, essa região foi privilegiada com investimentos industriais decorrentes de políticas nacionais de desenvolvimento regional e, dos anos 1970 para 1980, os esforços do governo federal para complementar a matriz industrial brasileira, com a produção de insumos básicos e bens intermediários, levaram à implantação de uma indústria de beneficiamento de cobre e de um grande Polo Petroquímico em um dos municípios dessa região metropolitana (Carvalho; Corso, 2008).

Esses e outros investimentos tiveram um impacto extraordinário sobre a velha capital baiana, convertendo a indústria no foco dinâmico da economia regional e modernizando e dinamizando essa economia, a ponto de, entre as décadas de 1970 e 1980, a região metropolitana de Salvador alcançar taxas de crescimento do PIB superiores às do Brasil. Salvador e os municípios circunvizinhos experimentaram um enorme crescimento populacional, e a estrutura social da região também se transformou, com uma ampliação e diversificação das classes médias e a emergência de um moderno (embora reduzido) proletariado industrial. Mas, como essas transformações incidiram sobre um mercado de trabalho marcado por uma superoferta de mão de obra de baixa qualificação, reforçada pela atração de significativos fluxos migratórios, persistiu a vinculação de uma grande parcela da força de trabalho a ocupações precárias e de baixa remuneração, impactando sobre as condições de pobreza e sobre as condições habitacionais de uma grande parte da população.

Como seria de esperar, essas mudanças também levaram a transformações radicais no tecido urbano, ocorridas de forma bastante rápida e abrupta nas décadas de 1960 e 1970, quando o Brasil como um todo se tornou predominantemente urbano. Elas foram marcadas pela realização de grandes obras públicas que acompanharam e anteciparam os vetores de expansão urbana, assim como por outras medidas governamentais que ampliaram e consolidaram o denominado "padrão periférico" de desenvolvimento urbano. Comprometida com uma modernização excludente e com os interesses do capital imobiliário, a Prefeitura de Salvador, que detinha a maioria das terras do município, transferiu essa propriedade para (muito poucas) mãos privadas; promoveu uma grande expansão do sistema viário e, entre outras providências, extirpou do tecido urbano mais valorizado um conjunto significativo da população pobre, transferindo seus moradores para a periferia mais distante e desvalorizada.

Essas e outras iniciativas, juntamente com as intervenções do capital imobiliário, redirecionaram a expansão da cidade e seus padrões de ocupação, levando à conformação de um espaço urbano onde, partindo do centro tradicional, configuram-se três vetores de expansão bastante diferenciados: a orla marítima, ao Norte, local privilegiado de moradia das classes altas e médias onde se concentram riqueza, investimentos públicos, equipamentos e serviços urbanos, pontos de atração turística e os interesses do capital imobiliário; o "Miolo" (assim denominado por estar situado no centro geográfico do município), que começou a ser ocupado com implantação de conjuntos habitacionais para as "classes médias baixas", e cuja maior parte das terras (consideradas como "não edificáveis" por sua extrema declividade), passou a ser objeto de loteamentos populares e ocupações ilegais, com uma disponibilidade de equipamentos e serviços bastante reduzida e uma população predominantemente pobre; finalmente, o Subúrbio Ferroviário, que teve a sua ocupação inicialmente impulsionada pela implantação de uma linha de trens, e que, com a expansão da cidade, passou a sediar um conjunto de loteamentos populares e ocupações ilegais, para onde foram transferidos, inclusive, moradores de áreas centrais remanejados pela Prefeitura. Trata-se de uma das áreas mais carentes e problemáticas da cidade, concentrando uma população bastante pobre e sendo marcada pela 
precariedade habitacional, pelas deficiências de infraestrutura, equipamentos e serviços e, mais recentemente, por altos índices de violência.

A Região Metropolitana de Salvador foi constituída a partir da implantação de novas e modernas atividades econômicas em municípios de base agrícola, localizados no entorno da capital baiana, envolvendo a extração de petróleo no município de Candeias, a instalação de uma refinaria em São Francisco do Conde e de um terminal marítimo em Madre de Deus, a implantação do Pólo Petroquímico em Camaçari e a crescente urbanização de Simões Filho e Lauro de Freitas, contribuindo para uma diferenciação significativa no âmbito da região. Conurbado com Salvador, Lauro de Freitas também tem concentrado moradores dos estratos altos e médios nos seus numerosos loteamentos e condomínios fechados. Embora a RMS não apresente nenhuma concentração operária, os trabalhadores da indústria moderna têm uma presença um pouco mais expressiva nos municípios que se desenvolveram a partir da exploração do petróleo e da indústria petroquímica, como Camaçari. Os demais municípios se caracterizam principalmente pela moradia das classes populares e de trabalhadores agrícolas, devendo ser ressaltado que, com a elevada concentração populacional em Salvador, cinco deles tinham menos de cinquenta mil habitantes no ano 2000.

\section{AS TRANSFORMAÇÕES DAS ÚLTIMAS DÉCADAS}

Privilegiadas pela dinâmica e pelas características do processo de desenvolvimento brasileiro, que concentrou no seu território a produção, a riqueza e as melhores oportunidades de trabalho e subsistência, as grandes metrópoles nacionais foram especialmente penalizadas a partir dos anos 80 , com o esgotamento do padrão de desenvolvimento até então implementado. Com o agravamento da crise econômica e da crise fiscal do Estado e uma intensa aceleração do processo inflacionário - mais tardiamente que em outros países - o governo brasileiro termi- nou por aderir, nos anos 1990, às recomendações do Consenso de Washington, aprofundando a inserção do Brasil no processo de globalização, com a realização de uma abertura econômica abrupta e rápida, um processo de reestruturação produtiva, um amplo programa de privatizações, uma redução do papel econômico e de regulação e das responsabilidades sociais do Estado e uma grande ênfase nos mecanismos de mercado.

Essas medidas agravaram significativamente o quadro social do país, em um período marcado por taxas de crescimento oscilantes e reduzidas, pela deterioração das condições de trabalho e renda da população e por uma acentuação das desigualdades sociais e espaciais, com impactos especialmente adversos sobre as grandes regiões metropolitanas, onde o mercado de trabalho era mais dinâmico e estruturado.

Diversos estudos têm demonstrado como, dos anos 1990 aos primeiros anos de 2000, ocorreu uma verdadeira desestruturação do mercado de trabalho no país e nessas regiões metropolitanas, com a destruição de milhares de postos de trabalho, principalmente no setor industrial, a fragilização e redução da importância relativa do núcleo estruturado (ou seja, do contingente de ocupados com vínculo empregatício formalizado e cobertura social), a proliferação de velhas e novas formas precárias de contratação e ocupação da mão de obra e um extraordinário crescimento do desemprego. (Carvalho, 2006; Borges, 2003; Pochman, 2008; CEPAL/PNUD/ OIT, 2008; Pasternak, 2009).

O impacto dessas transformações vem sendo analisado pelos pesquisadores do Observatório das Metrópoles, ${ }^{1}$ a partir da polêmica sobre os efeitos da reestruturação produtiva sobre a estrutura de classes e sobre a apropriação do espaço urbano desenvolvida a partir das já mencionadas discussões de Sassen (1998) e da sua hipótese

\footnotetext{
${ }^{1} \mathrm{O}$ INCT/Observatório das Metrópoles é uma rede de pesquisadores brasileiros, coordenada pelo Instituto de Pesquisa e Planejamento Urbano e Regional da Universidade Federal do Rio de Janeiro, que vem realizando, desde 1998 um amplo conjunto de estudos sobre a conformação e transformacões de algumas das principais metrópoles do país, a saber: Belém, Natal, Fortaleza, Recife, Salvador, Rio de Janeiro, Belo Horizonte, São Paulo, Curitiba, Porto Alegre, Goiânia e a aglomeração urbana de Maringá.
} 
sobre os nexos estruturais existentes entre as mudanças em curso na economia e a intensificação da dualização social. Nesse processo, em que o Setor Terciário estaria assumindo predominância frente a processos simultâneos de modernização e relativa retração no emprego do Setor Secundário, haveria igualmente uma reconfiguração e um encolhimento das classes médias, tendo em vista as mudanças na estrutura produtiva e nos padrões organizacionais e tecnológicos. Algumas ocupações típicas das classes médias estariam em declínio, outras se desqualificariam, e surgiriam novas profissões ligadas à expansão das funções de gestão (Sassen, 1998). A estrutura social, alicerçada na indústria da informação, em especial nas grandes metrópoles, estaria assentada, de um lado, na existência de profissionais altamente qualificados e bem remunerados e, de outro, em um contingente de trabalhadores menos qualificados e de não menor importância, como secretárias, faxineiros e trabalhadores de manutenção, configurando uma estrutura social no formato de ampulheta. Essa imagem, que não encontra unanimidade junto aos pesquisadores, estaria em contraposição à de um ovo, que representa a predominância das camadas médias e operárias na estrutura social e a presença reduzida dos estratos superiores e inferiores dessa estrutura.

Com pressupostos e metodologia semelhantes foi possível analisar e, de certa forma, comparar o impacto das mudanças econômicas contemporâneas sobre a estrutura social de São Paulo e de Salvador, assim como sobre o seu espaço urba- no, como será visto posteriormente. Trata-se, como foi assinalado, de duas metrópoles bastante distintas em termos de trajetória, escalas, estruturas produtivas e condições ocupacionais. Mas, além das características comuns às grandes cidades brasileiras, é exatamente essa diversidade que as torna representativas da múltipla realidade das metrópoles do país.

São Paulo possuía, em 2000, 17,8 milhões de habitantes e uma população ocupada de 7,12 milhões de habitantes (taxa de ocupação de 40\%), enquanto Salvador apresentava, no mesmo ano, uma população total de 3 milhões de pessoas e uma população ocupada de 1,11 milhão (taxa de ocupação de $37 \%$ ). As taxas de incremento demográfico também foram distintas no período 1991-2000, com São Paulo crescendo a uma taxa de 1,49\% ao ano e Salvador atingindo 2,16\% anuais. Uma semelhança entre as duas metrópoles foi o menor crescimento no núcleo metropolitano (São Paulo com 0,81\% anuais e Salvador com 1,85\% anuais) do que nos outros municípios da metrópole. O crescimento periférico foi dominante nas duas metrópoles, com taxas sempre maiores que na capital: a periferia de São Paulo com 2,55\% anuais e a de Salvador com $3,59 \%$ ao ano.

Capital do Estado mais desenvolvido do país e considerada por alguns como a sua "cidade global”, São Paulo comanda uma região metropolitana com uma estrutura produtiva poderosa e diversificada, como já foi visto, onde se destaca o peso das atividades industriais e dos serviços

Tabela 1 - Distribuição da vulnerabilidade nas 15 metrópoles selecionadas segundo a locação dos domicílios nos tipos socio-espaciais

\begin{tabular}{l|c|c|c|c|c|c}
\hline \multirow{2}{*}{ Ano } & \multicolumn{5}{|c}{ São Paulo } & \multicolumn{3}{c}{ Salvador } \\
\cline { 2 - 8 } & $\begin{array}{c}\text { Participação do } \\
\text { Município no } \\
\text { PIB Nacional }\end{array}$ & $\begin{array}{c}\text { Participação do } \\
\text { Município no } \\
\text { PIB da Indústria }\end{array}$ & $\begin{array}{c}\text { Participação do } \\
\text { Município no } \\
\text { PIB dos Serviços }\end{array}$ & $\begin{array}{c}\text { Participação do } \\
\text { Município no } \\
\text { PIB Nacional }\end{array}$ & $\begin{array}{c}\text { Participação do } \\
\text { Município no } \\
\text { PIB da Indústria }\end{array}$ & $\begin{array}{c}\text { Participação do } \\
\text { Município no dos Serviços } \\
\text { PIB do }\end{array}$ \\
\hline 2002 & 12,72 & 10,86 & 14,03 & 1,11 & 0,57 & 0,47 \\
\hline 2003 & 12,33 & 10,55 & 13,76 & 0,99 & 0,62 & 1,35 \\
\hline 2004 & 11,60 & 9,91 & 12,94 & 1,02 & 0,72 & 1,30 \\
\hline 2005 & 12,18 & 9,90 & 13,71 & 1,05 & 1,28 & 1,22 \\
\hline
\end{tabular}

Fonte: Censo Demográfico 2000, FIBGE. Tabulação Observatório das Metrópoles 
especializados. Só o município de São Paulo concentra em torno de 12\% do PIB nacional, 13\% do PIB de serviços e $10 \%$ do PIB industrial. Já Salvador se caracteriza como uma cidade de base terciária, com características econômicas mais modestas e uma participação no PIB em torno de 1\%, como a tabela I deixa patente, ainda que essa diferença deva ser relativizada pela dimensão populacional. (São Paulo possui 11 milhões de habitantes e Salvador 2,5 milhões).

Ainda que a queda relativa da produção e do emprego industrial ou o aumento da informalidade sejam comuns às duas cidades (assim como a outras metrópoles brasileiras), não se poderia esperar que os impactos dos fenômenos associados ao processo de globalização sobre realidades tão diferenciadas pudessem ser iguais. São Paulo, mais industrializada e desenvolvida, foi afetada principalmente na configuração do seu mercado de trabalho, com o setor terciário assumindo uma gradual predominância nas últimas décadas do século XX, frente a processos de modernização e relativa retração dos postos de trabalho no setor industrial, assim como a certa desconcentração desse tipo de atividade, com a transferência de empresas para outras regiões do estado e do país. Nesse processo, observou-se também a reconfiguração das classes médias, em razão de mudanças na estrutura produtiva e nos padrões organizacionais e tecnológicos, além do surgimento de novas profissões ligadas à expansão das funções de gestão.

Dados da RAIS (Relação Anual de Informações Sociais do Ministério do Trabalho), que cobrem o período de 1991 a 2000, atestam a redução do trabalho formal nas metrópoles de São Paulo e Rio de Janeiro, as maiores do país, onde o impacto da reestruturação produtiva parece ter sido mais intenso (a taxa de crescimento dos empregos formais de São Paulo no período foi de -0,28\% ao ano, e a do Rio de Janeiro, de -0,87\% anuais), inclusive porque, nessas metrópoles, o mercado de trabalho era mais bem estruturado. Se, em 1991, os empregados com carteira de trabalho constituíam $62 \%$ dos empregados, em 2000, esse percentual foi de apenas $51 \%$. Ao longo desse período, a
RMSP perdeu atividades industriais (a proporção de trabalhadores industriais entre os ocupados caiu de 27,35 em 1991 para 24,01\% no ano 2000) e ampliou o emprego em serviços, tanto entre os trabalhadores do terciário especializado (que passou de $15,19 \%$ para $19,34 \%$ ) como dos trabalhadores não especializados (que subiram de 13,71\% para 16,16\%).Entre os trabalhadores do secundário, a perda maior foi entre os da indústria tradicional, que representavam 9\% do total dos ocupados em 1991, passando a 4,6\% no ano 2000.

As tabulações dos empregos formais (RAIS/ CEMPRE) mostram as mesmas tendências de perda de emprego industrial e ganho de empregos no setor de serviços. Entre os 4.749.100 empregos formais na metrópole em 1991, 35,22\% estavam no setor industrial, $11,03 \%$ no comércio e $45,23 \%$ nos serviços. Já em 2000, com 4.630.809 empregos formais, esses percentuais eram $25,34 \%$, 15,12\% e 59,26\%. Dados de 2007 (6.160.103 empregos formais) confirmam essa tendência da perda de empregos na indústria. Nesse ano, os empregos industriais representaram apenas $23,71 \%$ do total de empregos formais na metrópole paulista. Mesmo o número absoluto de empregos industriais formais na Grande São Paulo, em 2007, computava cerca de 212 mil empregos a menos que em 1991, embora, entre 2000 e 2007, perceba-se certa recuperação. De outro lado, os empregos no comércio dobraram entre 1991 e 2007, tendo aumentado a uma taxa de $6,43 \%$ ao ano no período 2000 2007 , taxa $54 \%$ maior que o aumento do total de empregos formais no mesmo período. Os empregos em serviços tiveram incremento absoluto de 859 mil postos de trabalho. A taxa de aumento dos empregos em serviço foi de 3,97\% anuais entre 2000 e 2007, maior que no período 1991-2000, quando alcançou 2,60 \% anuais. Dessa forma, a tendência observada nos anos 90, de perda de empregos industriais e ganho no comércio e em serviços, se mantém nos anos 2000.

A evolução dos empregos formais de Salvador, no período 1991 a 2000, mostra tendências semelhantes em outro patamar: diminuição da proporção dos empregos na indústria (perda de $28 \%$ 
Inaiá M. M. de Carvalho, Suzana Pasternak, Lúcia M. Bógus

Tabela 2 - Empregos formais, por setor de atividade Regióes Metropolitanas de São Paulo e Salvador 1991 a $2007(\mathrm{em} \%)$

\begin{tabular}{l|c|c|c|c|r|r}
\hline \multirow{2}{*}{ Setor de atividade } & \multicolumn{3}{|c|}{ Sáo Paulo } & \multicolumn{3}{c}{ Salvador } \\
\cline { 2 - 7 } & 1991 & 2000 & 2007 & 1991 & 2000 & 2007 \\
\hline Indústria & 35,22 & 25,34 & 23,71 & 19,30 & 14,65 & 17,05 \\
\hline Comércio & 11,01 & 15,12 & 17,58 & 11,02 & 13,66 & 15,03 \\
\hline Serviços & 45,23 & 59,26 & 58,50 & 62,66 & 71,13 & 67,70 \\
\hline Agropecuária & 0,14 & 0,27 & 0,21 & 0,57 & 0,56 & 0,22 \\
\hline Outros / Ignorado & 8,37 & 0,03 & 0,00 & 6,45 & 0,00 & 0,00 \\
\hline Total & 100,00 & 100,00 & 100,00 & 100,00 & 100,00 & 100,00 \\
\hline
\end{tabular}

Fonte: Dados da RAIS/CEMPRE.

em São Paulo e 24\% em Salvador), aumento dos empregos no comércio (36,4\% em São Paulo e 23,9\% em Salvador) e nos serviços (31\% em São Paulo e 13,5\% em Salvador). Embora na mesma direção, em São Paulo as mudanças na estrutura do emprego formal foram mais intensas, tal como na população ocupada. A perda de empregos industriais teve maior intensidade, assim como o ganho nos serviços. Já na década de 2000 , percebe-se recuperação relativa dos empregos industriais formais na metrópole baiana: passaram a representar $17,05 \%$ do total de empregos formais nessa metrópole. Em números absolutos, a metrópole de Salvador compensou sua perda de quase $11 \mathrm{mil}$ postos de trabalho na indústria nos anos 90 com o ganho de quase 52 mil empregos industriais formais entre 2000 e 2007. A taxa de incremento de empregos industriais foi de 5,98\% nesse período, 1,6 vezes a taxa de crescimento do total de empregos, mostrando uma recuperação dos postos de trabalho na indústria. Nesse ponto, Salvador difere profundamente de São Paulo. Por outro lado, mais da metade do ganho de 204 mil empregos formais em Salvador e 1,53 milhões em São Paulo, no período 2000 a 2007, é devida ao aumento de empregos no setor de serviços.

Apesar do incremento das atividades do Setor Terciário, muitas vezes associado a uma perda de qualidade da ocupação, a metrópole paulista não reduziu suas taxas de desemprego, que persistiram elevadas: segundo dados da Fundação SEADE, no ano de 2000, a taxa de desemprego da população de 15 anos e mais era de $17,7 \%$. Na década de 1990, marcada pela abertura e pela reestruturação produtiva, São Paulo acusou perda de quase 120 mil postos formais de trabalho, conforme os dados da Tabela 3. A recuperação econômica que se deu a partir de 2005 é atestada pelo já citado incremento absoluto de 1,53 milhões de empregos formais no período 2000-2007.

Tabela 3 - Evolução dos empregos formais entre 1991 e 2007 - São Paulo e Salvador

\begin{tabular}{l|c|c}
\hline Empregos formais & São Paulo & Salvador \\
\hline 1991 & 4.749 .809 & 588.685 \\
\hline 2000 & 4.630 .809 & 702.172 \\
\hline 2007 & 6.160 .103 & 906.299 \\
\hline $2000-1991$ & -119.000 & 113.514 \\
\hline Taxa anual 1991-2000 & 1.529 .294 & 204.127 \\
\hline Taxa anual 2000-2007 & $4,16 \%$ & $3,71 \%$ \\
\hline
\end{tabular}

Fonte: RAIS 1991, 2000 e 2007.

Não foi exatamente essa a trajetória de Salvador, cuja região apresentara certo dinamismo na década de 1980, com a implantação do Polo Petroquímico de Camaçari. Apesar desse dinamismo, ela terminou por ser penalizada, na medida em que os efeitos adversos da abertura e da reestruturação produtiva se somaram ao abandono das políticas nacionais de desenvolvimento regional, à extrema concentração da riqueza estadual em alguns poucos municípios da Região Metropolitana, ao perfil da moderna indústria baiana e à conformação e fragilidade anterior de sua estrutura ocupacional. ${ }^{2}$ Ainda que a RMS tenha apresentado um saldo positivo de empregos formais entre 1991 e 2000 - com o ganho de mais 113 mil ${ }^{2}$ Salvador é capital da Bahia, um estado de base agrícola bastante populoso e relativamente menos desenvolvido, com diversas zonas estagnadas ou deprimidas, carente de cidades de porte médio mais dinâmicas no seu interior, que pudessem absorver as levas de migrantes da sua (ainda) numerosa população rural. 
postos de trabalho, saldo este que continua positivo entre 2000 e 2007, com ganho de 204 mil postos de trabalho formal -, a capital baiana e os principais municípios do seu entorno experimentaram uma verdadeira desestruturação do seu mercado de trabalho (Borges, 2003), com profundos reflexos sobre as suas condições sociais e urbanas.

A terceirização também avançou em ramos importantes da economia urbana, como os serviços financeiros e de utilidade pública (Carvalho; Almeida; Azevedo, 2001). Para a metrópole como um todo, a proporção dos trabalhadores ocupados no setor secundário, entre 1991 e 2000, passou de $21 \%$ para $19,4 \%$ do total de ocupados, mantendo a proporção de trabalhadores da indústria moderna em torno de $4 \%$ dos de ocupados e o de operários da indústria tradicional em torno de $3 \%$ desse total. Entre os trabalhadores do secundário, só houve redução significativa na proporção de operários dos serviços auxiliares.

Contudo a precariedade ocupacional se generalizou, atingindo, inclusive, segmentos antes protegidos, como os trabalhadores mais escolarizados e experientes, e a proporção de contribuintes à previdência diminuiu. Segundo estimativas de Pasternak (2009), entre 1991 e 2000, a taxa de informalidade passou de $29,7 \%$ para $37 \%$ na capital baiana, e o desemprego, antes mais restrito, afetou intensamente os segmentos mais desfavorecidos do mercado de trabalho, como os jovens, as mulheres, os negros e os trabalhadores de menor escolaridade, chegando a 25\% da PEA. Ademais, no ano 2000, o Censo Demográfico constatou que $28 \%$ dos ocupados na Região Metropolitana de Salvador tinham rendimento médio mensal, em todos os trabalhos, de até um salário mínimo; que a parcela dos moradores em condições de pobreza chegava a $46 \%$ e a daqueles em condições de indigência a $23,1 \%$, verificando-se tanto um processo de intensificação da pobreza e da indigência como uma reconcentração da renda na área entre 1991 e 2000. Se, em 1991, os mais pobres detinham 2,7\% da renda, em 2000, eles se apropriaram de apenas 1,7\%, enquanto a parcela dos mais ricos passou de $45,7 \%$ para $48,3 \%$ da renda total.
Com os dados obtidos nas pesquisas do Observatório das Metrópoles, pode-se observar melhor a estrutura sócio-ocupacional das duas metrópoles no período considerado e suas transformações. Para verificar a procedência ou não das teses da global city na realidade brasileira, foi elaborada uma hierarquia sócio-ocupacional, com a construção de um conjunto de categorias a partir das variáveis censitárias de ocupação, segundo a Classificação Brasileira de Ocupações (CBO), criada de acordo com as diretrizes da Classificação Internacional Uniforme de Ocupações (CIUO) da Organização Internacional do Trabalho (OIT). Os dados censitários são os únicos disponíveis no Brasil, com capacidade simultânea de comparabilidade no tempo e no espaço, contemplando dados do mundo do trabalho. Como pontos de referência, foram utilizados o sistema de classificação das profissões na França, adotado pelo Institut National d'Économie et Statistique (INSEE), e o primeiro trabalho comparativo realizado entre Paris e Rio de Janeiro (Preitecelle; Ribeiro, 1998).

Essas pesquisas têm como ponto de partida uma concepção multidimensional da estruturação do espaço social, o que permite alcançar uma compreensão mais refinada das eventuais posições sociais que os grupos de indivíduos ocupam e detectar as múltiplas escalas de hierarquização no espaço.

As categorias sócio-ocupacionais, através das quais é possível captar a segmentação social nas metrópoles brasileiras, foram construídas a partir de alguns princípios gerais que se contrapõem e que estão na base da organização da sociedade capitalista, tais como: capital e trabalho, grande e pequeno capital, assalariamento e trabalho autônomo, trabalho manual versus não-manual e, atividades de controle e de execução. Também foi levada em consideração a diferenciação entre setores da produção, como o Secundário e o Terciário, e, finalmente, entre os ocupados no Setor Secundário, foi feita uma distinção a partir da inserção dos trabalhadores nos segmentos modernos ou tradicionais da indústria. (Mammarella, 2007, p. 157)

Como as Tabelas 4 e 5 deixam patente, a Grande São Paulo se diferencia das metrópoles brasileiras pela maior concentração de ocupados das categorias superiores e médias, dos trabalhadores do secundário e dos profissionais de nível 
Inaiá M. M. de Carvalho, Suzana Pasternak, Lúcia M. Bógus

Tabela 4 - Estrutura sócio-ocupacional de São Paulo. Região, núcleo e periferia 1991 e 2000 (em percentual de ocupados)

\begin{tabular}{l|c|c|c|c|c|c}
\hline \multirow{2}{*}{ Grupos sócio-ocupacionais } & \multicolumn{2}{|c|}{ Metrópole } & \multicolumn{2}{c|}{ Núcleo } & \multicolumn{2}{c}{ Periferia } \\
\cline { 2 - 7 } & 1991 & 2000 & 1991 & 2000 & 1991 & 2000 \\
\hline Dirigentes & 2,16 & 1,37 & 2,59 & 1,59 & 1,34 & ${ }^{*} 1,03$ \\
\hline Profissionais de nível superior & 5,54 & ${ }^{*} 7,83$ & 6,65 & ${ }^{*} 9,48$ & 3,46 & ${ }^{* *} 5,29$ \\
\hline Pequenos empregadores & 3,14 & 2,65 & 3,55 & 3,08 & 2,37 & ${ }^{*} 1,98$ \\
\hline Categorias superiores & 10,84 & 11,85 & 12,79 & 14,15 & 7,17 & 8,30 \\
\hline Categorias médias & 32,03 & 28,15 & 33,73 & 30,29 & 28,82 & 24,85 \\
\hline Trabalhadores do terciário especializado & 15,19 & $* * 19,34$ & 15,14 & ${ }^{* *} 19,74$ & 15,29 & ${ }^{* *} 18,71$ \\
\hline Trabalhadores do secundário & 27,35 & 24,01 & 23,99 & 20,11 & 33,71 & 30,02 \\
\hline Trabalhadores do terciário não especializado & 13,71 & $* * 16,16$ & 13,69 & 15,51 & 13,73 & $* * 17,15$ \\
\hline Categorias populares urbanas & 56,25 & 59,51 & 52,82 & 55,36 & 62,73 & 65,88 \\
\hline Agricultores & 0,87 & ${ }^{*} 0,50$ & 0,66 & ${ }^{*} 0,21$ & 1,27 & ${ }^{*} 0,97$ \\
\hline
\end{tabular}

Fonte: Tabulações especiais dos Censos de 1991 e 2000; as categorias superiores são somatórias dos dirigentes, profissionais de nível superior e pequenos empregadores; as categorias populares são a soma dos trabalhadores do terciário especializado,

secundário e não especializado.

* redução maior que $20 \%$

** aumento maior que $20 \%$

Tabela 5 - Estrutura sócio-ocupacional de Salvador. Região, núcleo e periferia - 1991 e 2000 (em percentual de ocupados)

\begin{tabular}{l|c|c|c|c|c|c}
\hline \multirow{2}{*}{ Grupos sócio-ocupacionais } & \multicolumn{2}{|c|}{ Metrópole } & \multicolumn{2}{|c}{ Núcleo } & \multicolumn{2}{c}{ Periferia } \\
\cline { 2 - 7 } & 1991 & 2000 & 1991 & 2000 & 1991 & 2000 \\
\hline Dirigentes & 1,09 & 1,2 & 1,22 & 1,24 & 0,35 & $* * 1,00$ \\
\hline Profissionais de nível superior & 5,53 & $* * 6,54$ & 6,25 & 7,32 & 1,18 & $* * 2,75$ \\
\hline Pequenos empregadores & 2,28 & 2,43 & 2,35 & 2,53 & 1,88 & 1,96 \\
\hline Categorias superiores & 8,90 & 10,08 & 9,82 & $* * 11,09$ & 3,41 & $* * 5,75$ \\
\hline Categorias médias & 30,08 & 30,33 & 31,71 & 32,08 & 20,17 & 21,8 \\
\hline Trabalhadores do terciário especializado & 18,96 & 21,43 & 19,24 & 21,62 & 17,25 & $* * 20,51$ \\
\hline Trabalhadores do secundário & 20,9 & 19,38 & 18,75 & 17,52 & 34,01 & $28 /, 49$ \\
\hline Trabalhadores do terciário não especializado & 21,82 & 19,96 & 22,00 & 19,74 & 20,69 & 21,05 \\
\hline Categorias populares urbanas & 61,68 & 60,77 & 59,99 & 58,88 & 71,95 & 70,05 \\
\hline Agricultores & 1,61 & 1,15 & 0,84 & 0,84 & 6,35 & 4,41 \\
\hline
\end{tabular}

Fonte: Tabulações especiais dos Censos de 1991 e 2000; as categorias superiores são somatórias dos dirigentes, profissionais de nível superior e pequenos empregadores; as categorias populares são a soma dos trabalhadores do terciário especializado,

secundário e não especializado.

* redução maior que $20 \%$

** aumento maior que $20 \%$

superior. O peso das categorias médias fica em volta de $30 \%$ da população ocupada nas duas metrópoles, mas a Região Metropolitana de Salvador aparece com características marcantes de uma metrópole mais empobrecida, com percentuais relativos menores nas categorias superiores e maiores nas categorias populares urbanas, além de uma maior proporção de trabalhadores agrícolas, concentrados nos municípios menos desenvolvidos da sua periferia.

Com o avanço da urbanização, as duas metrópoles reduzem significativamente a participação desses últimos trabalhadores, tendo também em comum um aumento proporcional dos profissio- nais de nível superior. Mas a estrutura ocupacional de Salvador apresenta uma maior estabilidade que a de São Paulo, (pois as únicas categorias que apresentaram uma mudança significativa na década analisada foram os profissionais de nível superior, com aumento, e os trabalhadores agrícolas, com redução), que ganha uma proporção mais significativa de trabalhadores do terciário especializado e não especializado.

No núcleo metropolitano - as cidades de Salvador e São Paulo -, a estrutura sócioocupacional apresenta maiores diferenças: tanto em 1991 como em 2000, o município de São Paulo 
tem proporção maior de categorias superiores que Salvador e proporção menor de categorias populares urbanas. Mas nota-se que, na capital paulista, há perda de dirigentes, ganho de profissionais de nível superior e ligeira perda de pequenos empregadores, enquanto que, em Salvador, há certa manutenção dos dirigentes, ganho dos profissionais de nível superior e dos pequenos empregadores, resultando num ganho significativo das camadas superiores que não se observa em São Paulo, onde a expansão relativa foi dos trabalhadores do terciário não especializado. A capital de São Paulo perde trabalhadores do secundário, especialmente os da indústria moderna e tradicional. Alguns estudos indicam que as indústrias tradicionais saíram da metrópole e da capital em grande número, o que explica a perda de $52 \%$ na proporção de ocupados nessas indústrias na capital (a proporção de ocupados passou de 8,59\% em 1991 para 4,45\% no ano 2000). Isso acontece em menor escala em Salvador.

Analisando as informações a partir de três grandes grupos - superior, reunindo dirigentes, profissionais de nível superior e empregadores; médio e popular, com os trabalhadores manuais: comércio, serviços especializados e não especializados e operários industriais - pode-se concluir que, na década de 90, a metrópole de São Paulo não apresentou mudanças muito significativas na sua estrutura hierárquica. As categorias superiores tiveram um pequeno aumento relativo, passando de 10,85\% do total de categorias para $11,84 \%$, assim como os trabalhadores manuais, que passaram de 56,25\% para 59,50\%. Já a participação das categorias médias sofreu uma leve redução de 32,03\% para 28,15\%, números que estariam indicando certa tendência à polarização social. Foram os profissionais de nível superior os maiores responsáveis pelo aumento relativo das categorias superiores na década estudada, tanto na metrópole como um todo como no núcleo e nos demais municípios metropolitanos. Tanto profissionais autônomos como empregados de nível superior tiveram um crescimento de mais de $20 \%$ na década no contexto metropolitano.

De outro lado, o grupo dos dirigentes teve uma perda relativa de mais de $20 \%$, tanto no núcleo como nos demais municípios, associada principalmente ao decréscimo dos grandes empregadores. A redução desse grupo em números absolutos foi de quase 36 mil pessoas, em um total de 90 mil, ou seja, uma redução de praticamente $40 \%$. Podem-se esboçar algumas hipóteses para explicar esse fenômeno, hipóteses essas não mutuamente exclusivas: sua saída da metrópole, sua redução por falência, fusão ou venda de empresas (na década de 1990, muitas fecharam, sobretudo as de porte médio). Além disso, observa-se que uma parte desses dirigentes está se deslocando do núcleo para outros espaços da região metropolitana, onde se multiplicam os condomínios residenciais fechados.

A estrutura ocupacional de Salvador, analisada igualmente a partir dos 3 grandes grupos, mostra também uma estabilidade entre 1991 e 2000, com as categorias superiores por volta de $9 \%$, as médias variando de 30,08\% em 1991 para 30,33\% no ano 2000 e as categorias populares urbanas por volta de $61 \%$. Para as categorias superiores, foram os profissionais de nível superior os responsáveis pelo aumento na década. Diferentemente de São Paulo, há ligeiro aumento dos dirigentes, mais acentuado na periferia que no núcleo, o que talvez seja explicado pela expansão dos condomínios fechados, principalmente na orla de Lauro de Freitas. $\mathrm{O}$ peso das classes médias na estrutura social permanece significativo, associado, entre outros fatores, ao peso dos funcionários públicos na sua composição. Comparando a renda dessas camadas médias de Salvador com as de São Paulo, verifica-se que, em Salvador, essa renda não ia além de 3,63 salários mensais per capita em 2000, frente aos 5,24 salários registrados em São Paulo na mesma época. ${ }^{3}$

\footnotetext{
${ }^{3}$ Contudo, ao contrário do que se poderia esperar, a proporção de contribuintes da previdência era relativamente maior em Salvador (62,3\%) que em São Paulo (58\%), provavelmente pelo peso dos funcionários públicos na metrópole baiana. As categorias analisadas anteriormente também apresentam outras diferenças entre as duas regiões. Em decorrência das transformacões recentes de Salvador, suas categorias dirigentes estão mais próximas dos "cânones modernos", sendo relativamente mais jovem, com uma maior proporção de mulheres e de não -brancos e, curiosamente, auferindo uma renda média per capita de 16 salários mínimos, superior à dos dirigentes paulistas (com 14 salários). Entre esses últimos, a proporção de dirigentes nascidos no exterior chega a $31 \%$, pela presen-
} 
As categorias populares urbanas em Salvador experimentaram também uma pequena perda na década, passando de 20,9\% dos ocupados em 1991 para 19,38\% no ano 2000. Entre os trabalhadores do secundário, há perda significativa dos operários dos serviços auxiliares, diferentemente de São Paulo, onde são os únicos trabalhadores do secundário com aumento significativo. E tanto em São Paulo como em Salvador, os prestadores de serviços especializados (garçons, vigilantes, cozinheiros, além de trabalhadores de comunicação, TV e telefone, marceneiros, carpinteiros e semelhantes) foram os principais responsáveis pelo aumento notado, de 8,87\% em 1991 para 11,46\% no ano 2000. Em Salvador, não se nota, como em São Paulo, o aumento da base da pirâmide: a proporção de trabalhadores não especializados foi de $21,82 \%$ do total de ocupados em 1991, passando a $19,96 \%$ no ano 2000 , pois a retração do mercado de trabalho se refletiu principalmente em um aumento do desemprego, mais elevado na metrópole baiana que em todas as demais metrópoles brasileiras.

Salvador é uma metrópole extremamente desigual, com ilhas de afluência em meio a uma grande pobreza, onde 1,2\% de uma elite de grandes empregadores, dirigentes do setor público e privado, e de 6,55\% de profissionais de nível superior convivem com uma porção de $20 \%$ de trabalhadores do terciário não especializado. Em São Paulo, a uma elite de $1,37 \%$ e de $7,83 \%$ de profissionais de nível superior corresponde uma proporção de 16,16\% de trabalhadores do terciário não especializado, embora seja ela a única das grandes metrópoles brasileiras onde o aumento dessa categoria de trabalhadores foi paralelo ao crescimento dos profissionais de nível superior e a uma pequena perda do peso das categorias médias, mantendo certa tendência à polarização, apesar da relativa estabilidade da estrutura social.

São Paulo, como região mais industrializa-

ça dos executivos das multinacionais, embora essa proporção em Salvador também não seja desprezível, com $12 \%$ desses profissionais nascidos fora do Brasil. As categorias médias são igualmente mais jovens, femininas, e com 69\% de não -brancos em Salvador (em São Paulo, elas são pouco mais de 25\%). O nível de escolaridade é semelhante (10 anos de estudo, em média), apesar da grande diferença em termos de remuneração. da e desenvolvida, possui 40,35\% dos trabalhadores manuais urbanos no setor secundário, $32,50 \%$ ocupados no terciário e $27,16 \%$ no terciário não especializado. Já Salvador tem apenas 31,89\% dos seus trabalhadores manuais urbanos no setor secundário, 35,26\% no terciário e 32,85\% no terciário não especializado. No âmbito do setor secundário, as diferenças são ainda mais significativas, pois, enquanto em São Paulo 11,94\% dos trabalhadores manuais urbanos se encontram na indústria moderna e 10,63\% na construção civil, em Salvador esses números atingem 6,7\% e $13,13 \%$, respectivamente. Entre os ocupados no terciário não especializado de Salvador, os empregados domésticos chegam a 16,15\%, enquanto em São Paulo esse percentual não vai além de 12,14\%, sendo provavelmente esse um dos motivos que explicam a situação bem mais precária desses trabalhadores na metrópole baiana. ${ }^{4}$

Há diferenças entre os perfis das distintas categorias em São Paulo e Salvador, mas também pontos comuns. A grande distinção aparece entre as categorias dentro de cada metrópole. As desigualdades constituem uma marca básica das metrópoles brasileiras, maiores no Nordeste que no Sudeste. A renda média da elite baiana é maior que a da elite paulista, levantando a hipótese, referendada pela proporção de migrantes recentes nessa elite, que executivos e outros trabalhadores de elevada qualificação venham sendo atraídos por altos salários e bonificações para trabalhar na indústria e serviços modernos da região metropolitana de Salvador.

A partir dos dados apresentados, pode-se supor, também, que talvez a maior e mais rica metrópole brasileira tenha sido mais intensamente atingida pelos efeitos adversos das transformações

${ }^{4}$ Nas duas metrópoles, as mulheres representam mais de 70\% dos ocupados no terciário não especializado. Outras características desses trabalhadores, porém, são bastante diferenciadas. Em Salvador, os contribuintes da previdência não chegam a $9 \%$, enquanto em São Paulo eles representam $82 \%$ dessa categoria de trabalhadores. Na metrópole paulista, 53\% são brancos (e, sobretudo, nordestinos) e sua escolaridade média era de 6,03 anos de estudo no ano 2000, enquanto, na metrópole baiana, os brancos não representavam mais que $14 \%$ e a escolaridade média era de 5,29 anos. A maior diferença, porém, se encontrava na sua renda média per capita: 1,61 salários mínimos em Salvador e 2,14 salários em São Paulo. 
econômicas da última metade do século XX, uma vez que o seu mercado de trabalho era mais bem estruturado e que a indústria foi especialmente afetada pela reestruturação produtiva, no decorrer dessas transformações; que a estrutura ocupacional manteve certa estabilidade, tanto em São Paulo quanto em Salvador, ainda que associada a algumas novas tendências como: i) um avanço comum da profissionalização, com um significativo aumento dos profissionais de nível superior; ii) um processo de terciarização, com forte incremento dos trabalhadores do terciário especializado e não especializado em São Paulo, enquanto em Salvador os trabalhadores do terciário especializado registravam uma pequena expansão, mas os efeitos do ajuste e da reestruturação produtiva se manifestaram, sobretudo, no extraordinário aumento do desemprego; iii) uma desproletarização relativa, com um aumento dos operários dos serviços auxiliares e perda dos trabalhadores da indústria tradicional e moderna em São Paulo, e uma menor redução dos trabalhadores do secundário em Salvador, onde sua participação já era tradicionalmente mais restrita; iv) um relativo decréscimo do peso dos dirigentes (grandes empregadores, principalmente) em São Paulo, enquanto em Salvador ele se tornava um pouco mais expressivo; v) uma ampliação do número de trabalhadores não especializados (ambulantes, biscateiros e empregados domésticos) em São Paulo, enquanto em Salvador o seu peso sempre foi mais significativo.
Concluindo essas observações, vale lembrar que, nos primeiros anos deste novo milênio e, especialmente a partir de 2005, a economia brasileira recuperou certo dinamismo e o processo de desestruturação e precarização do mercado de trabalho que marcou a década de noventa se interrompeu, registrando-se um crescimento da ocupação e do emprego formal e certa redução do desemprego. Embora ainda não haja uma avaliação mais precisa dos impactos desse fenômeno sobre a estrutura social, há indícios de que teria ocorrido alguma melhoria das condições de ocupação e subsistência da população, favorecendo, sobretudo, aquelas metrópoles com maior capacidade de atrair os novos investimentos. As taxas de desocupação das duas metrópoles caíram a partir de 2005: a de Salvador ainda se mantém elevada, mas reduziu-se de 17,3 em 2005 para 14,2 em 2008; a de São Paulo também se reduziu, partindo de patamar menos elevado em $2005(13,4)$ e alcançando 9,0 em 2008.

Com o próximo Censo de 2010, esses impactos poderão ser mais bem avaliados, assim como a persistência (ou não) das tendências apontadas anteriormente. Ainda assim, a partir de dados das PNADs (Pesquisas Nacionais de Amostra por Domicílios) de 2001 a 2008, podem-se compatibilizar as variáveis pesquisadas para as grandes categorias sócio-ocupacionais, com o cuidado de não se compararem informações censitárias de 1991 e 2000 com os dados das PNADs de 2001 a 2008,

Tabela 6 - População ocupada, por grupo sócio-ocupacional, 2001, 2004 e 2008. Regiōes Metropolitanas de São Paulo e Salvador, em porcentagem

\begin{tabular}{|c|c|c|c|c|c|c|}
\hline \multirow{2}{*}{ Grupos Sócio-ocupacionais } & \multicolumn{3}{|c|}{ RM de São Paulo } & \multicolumn{3}{|c|}{ RM de Salvador } \\
\hline & 2001 & 2004 & 2008 & 2001 & 2004 & 2008 \\
\hline Dirigentes & 1,4 & 0,8 & 0,9 & 0,7 & 0,5 & 0,4 \\
\hline Profissionais de nível superior & 6,8 & 7,4 & 8,1 & 4,7 & 4,3 & 6,3 \\
\hline Pequenos empregadores & 2,7 & 2,7 & 2,3 & 2,7 & 2,2 & 1,6 \\
\hline Categorias superiores & 10,9 & 10,9 & 11,3 & 8,1 & 7,0 & 8,3 \\
\hline Categorias médias & 30,2 & 29,9 & 30,2 & 26,8 & 26,7 & 27,2 \\
\hline Trabalhadores do terciário & 18,6 & 20,8 & 21,0 & 19,7 & 21,4 & 20,9 \\
\hline Trabalhadores do secundário & 22,5 & 21,0 & 22,2 & 20,2 & 19,1 & 19,6 \\
\hline Trabalhadores do terciário não especializado & 17,2 & 16,7 & 14,7 & 23,4 & 24,0 & 22,9 \\
\hline Categorias manuais urbanas & 58,3 & 58,5 & 57,9 & 63,3 & 64,5 & 63,4 \\
\hline Agricultores & 0,7 & 0,7 & 0,6 & 1,7 & 1,9 & 1,2 \\
\hline
\end{tabular}

Fonte: Dados da RAIS/CEMPRE. 
devido a problemas metodológicos na construção das variáveis envolvidas.

Nota-se que, para a Região Metropolitana de São Paulo, a tendência de perda de dirigentes observada na década de 90 se mantém no início dos anos 2000: em números absolutos, essa perda atingiu, entre 2001 e 2007, mais de 16 mil ocupados, o que significa mais de 17\% dos dirigentes. Em 2008, tanto o peso relativo como o número absoluto desses dirigentes tornou a crescer, reduzindo-se a perda no período para menos de 10 mil. A profissionalização também se mantém como tendência: o peso relativo dos profissionais de nível superior aumenta em mais de 1 ponto percentual no intervalo entre 2001 e 2008, o que significa um incremento de quase $32 \%$ desses profissionais em 7 anos. As camadas médias mostraram-se relativamente estáveis, em torno de $30 \%$ do total de ocupados, evidenciando certo aumento relativo e absoluto em 2008, quando alcançaram $32 \%$ do total de ocupados. Em 1991 eram 32\%, e tinham se reduzido para $28 \%$ em 2000, pelos dados censitários. Entre as categorias manuais urbanas, a tendência ao seu aumento relativo não se manteve: seu peso se estabilizou em torno de $58 \%$ dos ocupados. No ano 2000, esse peso foi de 59,5\%. A terciarização, ou seja, o incremento dos trabalhadores do terciário, forte durante a década de 90, manteve-se. Entre 2001 e 2008, o aumento absoluto de trabalhadores do terciário na metrópole foi de 420 mil, dos quais 253 mil entre 2008 e 2006. A recuperação da economia após 2005 refletiu-se nesse incremento de ocupações terciárias, mostrando com clareza a mudança do perfil econômico da metrópole. A perda de ocupações no secundário da década de 1990 inverte-se: em 2001, os trabalhadores do secundário representavam 22,5\% do total de ocupados, percentual que se reduziu para $20,3 \%$ em 2003, tornando a subir para $21,2 \%$ em 2006 e se estabilizando em 22,2\% em 2008. Em números absolutos, entre 2001 e 2008, nota-se um ganho de 428 mil ocupados no secundário. Da mesma forma, muda a tendência de aumento da base da pirâmide evidenciada nos anos 90: o peso relativo dos trabalhadores do terciário não especializado reduzse de $17,2 \%$ dos ocupados em 2001 para 14,7\% em 2008, embora ,em números absolutos, perceba-se um incremento de 83 mil ocupados nessa categoria. Assim, nas categorias superiores, as tendências se mantêm e, nas manuais urbanas, mantém-se a terciarização, mas não a desproletarização e o ganho na base da pirâmide.

A estrutura social de Salvador apresenta distribuição relativa das categorias manuais urbanas maior que a paulista, com cerca de $63 \%$ da população ocupada nessa categoria, enquanto que, em São Paulo, seu peso relativo fica em torno de $58 \%$. E, dentro das categorias manuais urbanas, durante os anos 2000, notou-se um peso decrescente dos trabalhadores do secundário, que representavam 20,2\% do total de ocupados em 2001 e $18,3 \%$ em 2008, embora com crescimento do número absoluto em 81 mil trabalhadores. O peso relativo dos trabalhadores do terciário não especializado se mantém em $23 \%$ do total de ocupados, com aumento de 97 mil no período. A metrópole de Salvador mostra, como a paulista, tendência à terciarização: em 2001, o percentual de trabalhadores do terciário foi de 19,7\%, e sobe a $21 \%$ em 2007, atingindo $20,9 \%$ em 2008, com incremento de 110 mil trabalhadores no período 2001-2008. Esse aumento de terciários foi $43 \%$, superior ao incremento de $35 \%$ do total de ocupados. Assim, entre as tendências notadas nos ano 90, mantém-se a ligeira perda de trabalhadores do secundário, com manutenção relativa da base da pirâmide, mas surge tendência à terciarização, ausente dos anos 90.

Em relação às categorias médias, há manutenção do peso relativo, com oscilação em torno de $27 \%$ do total de ocupados. E, nas categorias superiores, uma estranha oscilação entre os dirigentes, que representavam $0,7 \%$ do total de ocupados em 2001, chegam a 2006 com o mesmo percentual, que cai para 0,4\% em 2008. Em números absolutos, os 9.500 dirigentes em 2001 sobem para 11.400 em 2006 e diminuem para $7.200 \mathrm{em}$ 2008. O dado difere fortemente do censitário de 1991 e 2000, que apresenta 1,2\% da população ocupada como dirigente. De outro lado, a tendência à profissionalização se mantém, com aumento do peso relativo dos profissionais de nível superior de $4,7 \%$ para $5,1 \%$ do total de ocupados. 
Assim, as duas metrópoles apresentam em comum, nos anos 2000, tendênciaà profissionalização e à terciarização. Em Salvador, mais que em São Paulo, percebe-se leve desproletarização. E, nas duas, nos anos 2000, não se pode falar em aumento da base da pirâmide social, apesar de esse aumento ter sido visível em São Paulo na década de 90. As camadas médias permanecem estáveis.

\section{AS TRANSFORMAÇÕES SOCIOESPACIAIS}

A partir das colocações teóricas sobre a tendência à dualização social e urbana das grandes metrópoles, diversos autores têm polemizado a respeito dos impactos das transformações em apreço sobre os padrões de apropriação e utilização do solo urbano, e, no caso do Brasil e de outros países latino-americanos, sobre a persistência do modelo centro-periferia que marcou a sua urbanização. A questão básica, conforme Marcuse e Van Kempem (2000), é se há algo distinto nas cidades atuais em relação às cidades de ontem. $\mathrm{O}$ que haveria de novo nas cidades (particularmente na estrutura intraurbana) e qual seria a repercussão das mudanças na economia e na estrutura social em termos de um possível aumento das desigualdades? Embora reconheçam que a globalização não produz, diretamente, um determinado padrão espacial, os autores levantam a hipótese de que as transformações a ela associadas estariam levando a uma nova ordem urbana, com a concentração espacial de uma nova pobreza, de um lado, e de atividades altamente especializadas e internacionalizadas, de outro, com o aumento das divisões espaciais, das fronteiras e dos muros físicos e sociais entre as classes e a constituição de cidades cada vez mais fracionadas e segregadas.

A tese de que os processos de globalização e de terciarização provocariam um aumento da polarização social e da desigualdade espacial tem sido contestada por autores como Preteceille (1995) ou Hamnett (1994), apontando que, em Paris e Londres, a evolução se deu de outra maneira. Maldonado (2000) também assinala que, em Madri, o resultado das mudanças foi a elevada profissionalização das categorias sociais, com um crescimento das camadas médias e uma redução das desigualdades. Apesar dessa polêmica, há um consenso na literatura de que as transformações contemporâneas, com as mudanças nas formas de produção, o declínio da intervenção estatal, as novas tecnologias e distintas relações de poder influenciam os padrões de urbanização e a morfologia das cidades.

Utilizando-se a metodologia do Observatório das Metrópoles, (cuja base é uma tipologia socioespacial que classifica de forma hierárquica as diversas áreas que compõem o espaço metropolitano) e comparando-se o que foi observado em 1991 e em 2000, essa influência foi analisada para São Paulo e para Salvador. ${ }^{5}$ Essa tipologia foi construída com base nos dados censitários sobre a ocupação da população economicamente ativa, considerando a distribuição das categorias ocupacionais apresentadas anteriormente no espaço de cada metrópole, utilizando-se, como recorte territorial, áreas definidas por uma agregação dos setores censitários utilizados no Censo de 2000 pelo IBGE: as Áreas de Expansão Domiciliar (AEDS).

${ }^{5}$ Essa tipologia foi construída com base nos dados censitários sobre a ocupação da população economicamente ativa, considerando a distribuição das categorias ocupacionais apresentadas anteriormente no espaço de cada metrópole, utilizando-se, como recorte territorial, áreas definidas por uma agregação dos setores censitários utilizados no Censo de 2000 pelo IBGE: as Áreas de Expansão Domiciliar (AEDS).

Para São Paulo, essa tipologia abrange 12 tipos de áreas em 2000, que foram agrupadas em 5 grandes tipos: áreas do tipo superior, que apresentam $31 \%$ dos ocupados em categorias superiores; áreas médias, que tinham 11\% dos seus ocupados residentes nas categorias superiores, $33 \%$ nas ocupações médias e $55 \%$ como trabalhadores manuais urbanos; áreas operárias, com 35\% dos seus ocupados como trabalhadores do secundário, $22 \%$ em ocupações médias e apenas 4\% como categorias superiores; áreas populares, com 35\% dos seus ocupados como trabalhadores do terciário não especializado e operários da construção civil e apenas $2,7 \%$ nas categorias superiores; e $20 \%$ nas ocupações médias e áreas agrícolas, com 12\% de seus trabalhadores em ocupações agrícolas. Em Salvador, a composição das áreas superiores, médias e populares é similar à de São Paulo. Pelas especificidades da metrópole baiana, contudo, que não possui uma classe operária significativa nem espaços urbanos com essa composição, a tipologia também abarca áreas do tipo popular inferior, que se destacam pela elevada concentração de prestadores de serviços não qualificados, trabalhadores domésticos, ambulantes e biscateiros, e, em municípios da região metropolitana, áreas classificadas como popular agrícola ou popular operário agrícola; nesse último caso, trata-se de municípios pequenos, de base popular agrícola, que, na sua (reduzida) população ocupada, englobam também trabalhadores da indústria do petróleo. 
Como seria de esperar, pela própria natureza da estrutura urbana, no que tange aos padrões de apropriação e utilização do território e à conformação metropolitana, as transformações foram menos evidentes, pois as características do processo de urbanização do Brasil levaram à constituição de metrópoles bastante desiguais e segmentadas.

Em São Paulo, as áreas superiores ficaram concentradas como uma mancha no centro da metrópole, percebendo-se uma hierarquia descendente dos tipos socioespaciais conforme a distância em relação a essa mancha, quebrada apenas por algumas "manchas" superiores menores na zona oeste e por uma pequena "mancha" superior a leste. As áreas superiores geralmente estão circundadas por áreas médias, também localizadas principalmente na capital. Essa organização do espaço corresponde ao modelo tradicional de segregação espacial, que é a de círculos concêntricos, com as camadas de alta renda residindo nos círculos mais centrais e as camadas de menor renda nos círculos contíguos, em direção à periferia. No caso de São Paulo, essa estrutura espacial ainda se mantém de maneira bastante acentuada, embora comece a apresentar uma mistura social crescente. Vale ressaltar, conforme Villaça (1997), que a estrutura social desigual presente nas cidades brasileiras impediu que esse modelo de segregação em círculos concêntricos fosse dominante, prevalecendo, para as áreas de elite, o modelo de "setores de círculo", instalados numa mesma direção a partir do centro principal de cada cidade. Ainda segundo Villaça (1998), as localizações assim produzidas são privilegiadas pela instalação de infraestrutura urbana e por outros atributos que garantem o seu caráter de exclusividade e reforçam a segregação.

A partir da lógica de estruturação espacial responsável por sua configuração, registra-se, na RMSP, a presença de municípios tradicionalmente ligados à produção fabril, como Diadema, Santo André e São Bernardo a sudeste, Osasco a oeste, Guarulhos a leste e Cajamar ao norte. Nesses municípios, é marcante, ainda hoje, a presença de grandes áreas operárias, ainda que a maior parte da periferia seja ocupada por áreas do tipo popular e agrícola popular.

Em Salvador, os processos que levaram à expansão da capital baiana e à constituição de sua região metropolitana também produziram uma apropriação do espaço bastante desigual. Na Orla Marítima de Salvador e do município de Lauro de Freitas, concentram-se os espaços superiores e médio superiores, em uma mancha praticamente contínua, interrompida por alguns raros espaços de tipo popular. Os espaços médios estão principalmente no centro e em áreas de ocupação mais antiga, assim como em poucos trechos do Miolo e do Subúrbio Ferroviário. Nesses dois vetores e nos demais municípios da região metropolitana, encontram-se os espaços de base popular ou popular agrícola.

Em ambas as metrópoles, esse padrão de ocupação se manteve ao longo da década passada, embora essa relativa persistência seja paralela a algumas transformações em menor escala, na medida em que diversas áreas apresentaram tendências a: i) elitização, com um aumento das categorias superiores entre os seus residentes; ii) profissionalização, com o crescimento dos profissionais de nível superior; iii) terciarização, com uma maior presença de trabalhadores do setor terciário; iv) desproletarização ou proletarização, com a redução ou um aumento dos ocupados no setor secundário; e v) popularização, com uma ampliação do contingente de trabalhadores do terciário não especializado.

Confirmando a tendência a uma maior exclusividade e autossegregação das camadas de mais alta renda, elas permanecem ou se deslocam para as áreas mais valorizadas da metrópole, aumentando essa valorização e impondo limites à entrada de outros segmentos com menor poder aquisitivo. Observa-se, também, o deslocamento de parte dessas camadas de alta renda para condomínios fechados nas novas fronteiras de expansão do capital imobiliário na periferia. Com isso, as áreas superiores vêm se elitizando nas diversas metrópoles brasileiras (Lago; Mammarella, 2009), ainda que, em algumas delas, se observe a verticalização, 
com a substituição de antigas mansões por prédios de apartamentos que atraem, de modo crescente, moradores das classes médias. Os espaços médios, por seu lado, vêm apresentando múltiplas tendências, como a terciarização, a profissionalização e a desproletarização. Os espaços operários, bastante significativos em São Paulo, mas praticamente inexistentes em Salvador, vêm apresentando tendências à terciarização e à popularização. Já os espaços populares geralmente mantêm a sua composição, ainda que alguns deles venham atraindo moradores das classes médias e outros tenham se deteriorado com a desestruturação do mercado de trabalho, o crescimento do desemprego, a ampliação das carências, a expansão do tráfico de drogas e o crescimento da violência, experimentando o que Waquant (2008) qualifica como um processo de "descivilização".

Apesar da tendência à elitização das áreas superiores, o maior espraiamento das camadas médias e superiores no território metropolitano vem ampliando a sua diversificação social. Embora não se possa dizer que o padrão centro-periferia esteja superado, metrópoles como São Paulo e Salvador tornaram-se mais segmentadas e, de certa forma, um pouco menos segregadas em termos espaciais, ainda que a proximidade física entre as diversas classes possa estar associada a uma maior distância social, como os condomínios fechados deixam patente. A isso se somam algumas outras mudanças, observadas em vários estudos sobre as demais metrópoles da América Latina (Ribeiro, 1999; Mattos, 2004; Duhau, 2005; Veiga, 2005; Bayon, 2008; Lago; Mammarella, 2009), em que sobressaem:

- O decréscimo e o esvaziamento de antigas áreas centrais, como o centro histórico de Salvador e de São Paulo, com o deslocamento de áreas tradicionais de negócios e a constituição de novas centralidades, algumas associadas à proliferação de artefatos de grande impacto na estruturação do espaço urbano, como complexos empresariais, grandes centros do comércio e serviços ou centros de convenções, como se observa nas avenidas Faria Lima e Berrini em São Paulo ou na
Avenida Tancredo Neves e em suas adjacências em Salvador.

- A difusão de novos padrões habitacionais e investimentos imobiliários destinados às camadas de alta e média renda, com destaque para os condomínios horizontais fechados, que vêm se expandindo em áreas como Barueri, Santana do Parnaíba e Cotia, na região metropolitana de São Paulo, ou na orla marítima de Lauro de Freitas, na de Salvador. São condomínios implantados geralmente em áreas antes mais afastadas e ocupadas pelas camadas populares ou por atividades agrícolas, mas com uma segmentação agora mais acentuada, que se expressa por meio de dispositivos explícitos de separação física e simbólica, como cercas, muros e sofisticados aparatos de segurança, cujo objetivo é proteger seus moradores da violência e de outras mazelas da grande cidade.

- Uma expansão das metrópoles para as bordas e para o periurbano, com o espraiamento da moradia das camadas de mais baixa renda para áreas cada vez mais afastadas, associada não apenas ao crescimento da população como às transformações do mercado de trabalho, que tem levado os trabalhadores da base da pirâmide à busca de menores custos com habitação.

- Uma afirmação crescente da lógica e dos interesses do capital imobiliário na produção e reprodução metropolitanas, alterando a paisagem e as condições urbanas, entre outros motivos, pela incorporação do discurso sobre as cidades globais e do empreendedorismo urbano a ele associado. Em Salvador, esse fenômeno tem se exacerbado, a ponto de a Prefeitura local ter encampado um conjunto de 22 projetos de intervenção "doados à cidade” por empresas do setor imobiliário ou fundações a elas associadas, com o pomposo título de "Salvador a Capital Mundial”. Não por acaso essas intervenções se concentram na Orla Marítima e em algumas outras áreas de especial interesse do referido setor. 


\section{CONSIDERAÇÕES FINAIS}

Partindo das discussões teóricas sobre o impacto da globalização nas grandes regiões metropolitanas e com base na trajetória recente de São Paulo e de Salvador, o presente artigo tenta responder a quatro questões básicas. Há algo distinto na evolução da estrutura social das duas metrópoles brasileiras - São Paulo e Salvador? Qual o impacto da reestruturação dos sistemas produtivos induzidos pelas inovações tecnológicas e pelas exigências de um mundo globalizado nessas metrópoles? Qual a relação entre as transformações na estrutura social e as alterações no padrão de segmentação espacial do espaço intrametropolitano de São Paulo e Salvador? As mudanças sociais e espaciais nas duas metrópoles caminham no mesmo sentido?

Como foi visto, a estrutura social das duas metrópoles difere bastante: a de São Paulo apresenta cerca de $10 \%$ nas categorias superiores, $30 \%$ nas médias e $58 \%$ nas categorias populares urbanas; a de Salvador, $8 \%$ nas superiores, $27 \%$ nas médias e $63 \%$ nas categorias populares urbanas. Esses perfis têm se mantido nas duas décadas estudadas, associados a algumas novas tendências. Nas duas metrópoles, há um avanço na profissionalização, bem mais intenso em São Paulo do que em Salvador, com um significativo aumento dos profissionais de nível superior; uma desproletarização relativa, com perda dos trabalhadores da indústria tradicional em São Paulo, compensada pelo incremento de operários nos serviços auxiliares entre 1991 e 2000; mais recentemente, essa tendência diminuiu, com uma recuperação dos empregos formais no secundário; em Salvador, também ocorreu uma redução dos trabalhadores no secundário, embora sua participação na estrutura ocupacional tenha sido sempre mais restrita; entre 1991 e 2000, ocorre um decrescimento relativo e absoluto dos dirigentes em São Paulo e a manutenção do seu peso relativo em Salvador, mas, na década de 2000, essa tendência se inverte, mostrando como a recuperação econômica após 2005 teve efeitos distintos nas duas metrópoles; entre
1991 e 2000, anos de crise, São Paulo apresenta uma ampliação do número e do peso relativo dos trabalhadores do terciário não especializado. Após a crise dos anos 2000, essa tendência se inverte: Salvador apresenta um peso relativo maior desses trabalhadores (23\%, contra 15\% na metrópole paulista em 2007). Aliás, esse peso relativo se mantém estável desde 1991.

Nas duas metrópoles, as camadas médias representam percentual grande, maior em São Paulo que em Salvador. Não se percebe evidência de redução de seu peso relativo em nenhuma das duas metrópoles, como tem afirmado a literatura sobre globalização. Na metrópole paulista, a reestruturação produtiva é notada pela redução dos trabalhadores do secundário e aumento do terciário e dos empregos em serviços. Mas os dados das PNADs desmentem a hipótese de uma polarização crescente, pois não se percebeu aumento na base da pirâmide social e nem do extremo topo. Em Salvador, o emprego formal também avançou nos anos 2000, com a criação de mais de 200 mil postos entre 2000 e 2007, sendo $56 \%$ deles nos serviços e $25 \%$ na indústria. Mas, apesar do aumento do número absoluto de trabalhadores do secundário, entre 2001 e 2007, há perda do seu peso relativo. Assim, nas duas metrópoles, percebe-se tendência à desproletarização.

São Paulo, a maior e a mais rica metrópole brasileira, foi intensamente atingida tanto pelos efeitos adversos das transformações econômicas da última década do século XX como pela recuperação dos anos 2000. Com uma estrutura produtiva bastante complexa, um mercado consumidor ampliado pela dimensão e renda da sua população e uma maior disponibilidade de serviços produtivos, São Paulo tem se beneficiado da referida recuperação, persistindo como um importante centro industrial e concentrando crescentemente os serviços superiores. Em 2008, por exemplo, ali estavam localizadas $41,6 \%$ das sedes das 100 maiores empresas do Brasil e 61\% das sedes dos 100 maiores bancos.

Se as mudanças na estrutura ocupacional foram diferenciadas e complexas, a estrutura só- 
cio-espacial apresentou uma maior inércia. Mas, na trajetória recente, tanto em São Paulo como em Salvador, houve um avanço de alguns processos, como o esvaziamento dos centros históricos, um maior isolamento das elites (em São Paulo, 70\% dos dirigentes concentravam-se nas áreas superiores no ano 2000) e a manutenção de um padrão de crescimento periférico, com camadas populares residindo cada vez mais longe; de outro lado, apesar do isolamento das elites e da localização cada vez mais longínqua das camadas pobres, percebe-se maior mistura social no resto das áreas. Como se vê, o paradigma das cidades globais, marcadas pela maior polarização social e uma crescente dualização do espaço, parece muito pouco adequado para analisar e compreender as transformações atuais das metrópoles brasileiras.

(Recebido para publicação em julho de 2009 (Aceito em agosto de 2010)

\section{REFERÊNCIAS}

BOGUS, Lucia Maria Machado; VERAS, Maura Pardin Bicudo. A reorganização metropolitana de São Paulo: espaços sociais no contexto da globalização. Cadernos Metrópole. São Paulo, EDUC, n.3, p.105-128, 1991.

; PASTERNAK, Suzana. Como anda São Paulo. Rio de Janeiro: Letra Capital, 2009.

BAYON, Maria Cristina. Desigualdad y procesos de exclusion social. Concentracion socioespacial de desvantajas em el gran Buenos Aires y la Ciudad de México. Estúdios Demográficos y Urbanos. México, El Colégio de México, v.23, n.67, n.1, enero-abril p.123-150, 2008.

BORJA, Jordi; CASTELS, Manuel. Local e global. La gestión de las ciudades en la era de la información. Madrid: Taurus, 1997

CARVALHO, Inaiá M. M. de. Globalização, metrópoles e crise social no Brasil. Revista EURE, Santiago do Chile, v.32, n.A5, p.5-20, 2006,

- PEREIRA, Gilberto Corso. (Org.) Como anda Salvador. 2.ed. Salvador: EDUFBA, 2008.

; ALMEIDA, Paulo Henrique; AZEVÊDO, José Sérgio G. Dinâmica metropolitana e estrutura social em Salvador. Tempo Social: revista de sociologia da USP. São Paulo, v.13, n.2, p.89-114, 2001.

HAMNETT, Chris. Social polarization in global cities: theory and evidences. Urban Studies, Glasgow,UK, n.31, 1994.

LAGO, Luciana Correia do; MAMMARELLA, Rosetta. Da hierarquia de classes à organização do espaço intra-urbano: um olhar comparativo sobre as grandes metrópoles brasileiras. In: ENCONTRO ANUAL DA ANPOCS,33, Caxambu, 2009. Anais... Caxambu, 2009. 22 p.
MALDONADO, Jesus Leal . Economia, emprego e desigualdade social em Madri. In: QUEIROZ RIBEIRO, Luis Cesar (Org.) O futuro das metrópoles: desigualdade e governabilidade. Rio de Janeiro: Revan; FASE, 2000, p.177-204.

MAMMARELLA, Rosetta. BOx II Panorama da estrutura sócio-ocupacional nas Regiões Metropolitanas do Brasil In: QUEIROS RIBEIRO, Luis Cesar; SANTOS JUNIOR, Orlando A. (Org.) As metrópoles e a questão social brasileira. Rio de Janeiro: Revan; Observatório das Metrópoles, p.157-159.

MARCUSE, Peter: KEMPEN, Ronald. Globalizing cìties: a news spatial order? London: Backwell, 2000.

MATOS, Carlos A. de. Redes, nodos e cidades: transformação da metrópole latino americana. In: RIBEIRO, Luiz César Q. (Org.) Metrópoles. Entre a coesão e a fragmentação, a cooperação e o conflito. São Paulo: Editora Perseu Abramo; Rio de Janeiro: FASE;Observatório das Metrópoles, 2004.

PASTERNAK, Suzana. Mudanças na estrutura sócioocupacional das metrópoles brasileiras. 1991-2000. São Paulo, 2009, 40 p. (Relatório de pesquisa)

POCHMANN, Márcio. O emprego no desenvolvimento da nação. São Paulo: Boitempo, 2008. 238p.

PRETECEILLE, Edmond Division sociale de l'espace et globalization: les cas de La metrópole parisienne. Societés Contemporaines, Paris, 22, 1995. p.33-68

; RIBEIRO, Luiz Cesar Q. Estrutura social e segregação urbana: um estudo comparativo: Rio de Janeiro e Paris. In: ENCONTRO ANUAL DA ANPOCS,22 Caxambu, MG. 1998. Anais... Caxambu: ANPOCS, 1998.

RIBEIRO, Luiz César Q.; LAGO, Luciana. O espaço social nas grandes metrópoles brasileiras: São Paulo, Rio de Janeiro e Belo Horizonte. Revista Brasileira de Estudos Urbanos e Regionais. Belém,PA, ANPUR, n.3, p.111-129, 2000.

SASSEN, Saskia. The global city. New York, London, Tokyo. New Jersey: Princeton University Press, 1991.

VELTZ, Pierre. Mondialisatiom, villes et territoires. L'economie d'archipel. Paris: Press Universitaires de France, 1996.

VILLAÇA, Flávio. Efeitos do espaço sobre o social na metrópole brasileira. In: ENCONTRO NACIONAL DA ASSOCIACÃO NACIONAL DE POS-GRADUACÃO E PESQUISA EM PLANEJAMENTO URBANO E REGIONAL,8, Anais... Recife, 1997. 


\section{METROPOLITAN TRANSFORMATIONS: São Paulo and Salvador}

\author{
Inaiá Maria Moreira de Carvalho \\ Suzana Pasternak \\ Lucia Machado Bógus
}

This paper aims to discuss the impacts of the globalization process on Brazilian metropolises based on a comparative analysis of the recent trajectory of São Paulo and Salvador, which provides rich information for this discussion. Starting from the current literature on this topic, the paper analyzes the extent to which the phenomena associated with this process are leading to greater changes in the social and urban structures of these agglomerations. It is noted, with this analysis, that they present some stability next to some changes, whose diversity and complexity are not being addressed by the most current theoretical formulations.

KEYwords: cities, globalization. metropolitan transformations São Paulo, Salvador.

\section{TRANSFORMATIONS MÉTROPOLITAINES: Sao Paulo et Salvador}

\author{
Inaiá Maria Moreira de Carvalho \\ Suzana Pasternak \\ Lúcia Machado Bógus
}

Cet article se veut d'ouvrir une discussion à propos des impacts du processus de mondialisation sur les grandes métropoles brésiliennes, fondée sur l'analyse comparative de la trajectoire récente de Sao Paulo et de Salvador qui apporte de riches informations à cette discussion. À partir de la littérature actuelle concernant ce sujet, on examine dans quelle mesure les phénomènes associés à ce processus mèneraient à de plus amples transformations au sein de la structure sociale et urbaine de ces agglomérations. Grâce à cette analyse, on en arrive à la constatation qu'elles présentent une certaine stabilité à côté des quelques changements dont la diversité et la complexité ne sont pas prises en considération dans les formulations théoriques les plus courantes.

MотS-CLÉs: métropoles, globalisation, mondia-lisation, transformations métropolitaines, São Paulo, Salvador.

Inaiá Maria Moreira de Carvalho - Doutora em Sociologia pela Universidade de São Paulo.P rofessora do Mestrado em Políticas Sociais e Cidadania da Universidade Católica do Salvador e do Programa de Pós-Graduação em Ciências Sociais da Universidade Federal da Bahia - UFBA. Pesquisadora do Centro de Recursos Humanos - CRH/UFBA. Bolsista de produtividade em pesquisa do CNPq e coordenadora do núcleo do INCT/ Observatório das Metrópoles de Salvador. Suas pesquisas abordam temas como mercado de trabalho, transformações urbanas, pobreza e políticas sociais. Entre os seus trabalhos mais recentes que enfocam a questão das cidades estão os livros Como Anda Salvador (Rio de Janeiro, Letra Capital, 2009) e $2^{\mathrm{a}}$ edição, atualizada e ampliada (Salvador, EDUFBA, 2008) organizados em colaboração com Gilberto Corso Pereira, e os artigos Globalização, Metrópoles e Crise Social no Brasil (EURE, Santiago, 2006), Dinâmica Metropolitana e Segregação Socioespacial (Caderno CRH, n. 50, Salvador, 2007) e Dinâmica de una Metropoli Periferica en Brasil (Estudios Demograficos y Urbanos, México, 2010) os dois últimos em colaboração com Gilberto Corso Pereira.

Suzana Pasternak - Doutora em Saúde Pública pela Universidade de São Paulo, tem curso de especialização em Urbanismo pela Université Paris I (Pantheon- Sorbonne) e em Saúde Pública pela Universidade de São Paulo. Professora titular da Faculdade de Arquitetura e Urbanismo, coordenadora do núcleo do INCT/Observatório das Metrópoles de São Paulo. Bolsista de produtividade de pesquisa do CNPq. Tem experiência na área de Planejamento Urbano e Regional com ênfase em Fundamentos do Planejamento, atuando principalmente nos seguintes temas: favela, habitação popular, estudos urbanos. Entre as suas publicações mais recentes estão a coletânea Como Anda São Paulo (Rio de Janeiro, Letra Capital, 2009) que organizou com Lúcia Bógus, e o artigo e capítulos do livro Dinâmica espacial da la desigualdad (Ciudades, Puebla, 2008), Análise comparativa da questão de habitação nas metrópoles (Rio de Janeiro, Revan, 2007) e A favela que virou cidade (Rio de Janeiro, Mauad X, 2008).

Lúcia Maria Machado Bógus - Doutora em Arquitetura e Urbanismo pela Universidade de São Paulo. Professora titular da Pontifícia Universidade Católica de São Paulo. Editora da revista Cadernos Metrópoles. Bolsista de produtividade em pesquisa do CNPq. Tem experiência na área de Demografia, com ênfase em políticas públicas, planejamento urbano e análises populacionais, atuando principalmente nos seguintes temas: migração, urbanismo, desigualdade social, cidade e distribuição espacial da população. Coordenadora do núcleo do INCT/ Observatório das Metrópoles em São Paulo e entre as suas publicações mais recentes estão as coletâneas Como Anda São Paulo (Rio de Janeiro, Letra Capital, 2009) que organizou com Suzana Pasternak, e Desigualdade e a Questão Social, com L. E. Wanderley e M. Wanderley, os artigos Dinâmica espacial de la desigualdad (Ciudades, Puebla, 2008) e como Anda São Paulo (São Paulo, Caderno Metrópoles, 2006) em colaboração com Suzana Pasternak assim como capítulo do livro Segregação Urbanas (Coimbra, Ed. Almadina, 2009). 